\title{
Traditional dietary adjuncts for the treatment of diabetes mellitus
}

\author{
BY SARA K. SWANSTON-FLATT AND PETER R. FLATT \\ Biomedical Sciences Research Centre and Department of Biological and Biomedical Sciences, \\ University of Ulster, Coleraine BT52 1SA
}

\author{
AND CAROLINE DAY AND CLIFFORD J. BAILEY \\ Department of Pharmaceutical Sciences, Aston University, Birmingham B4 7ET
}

Before the introduction of insulin in 1922 treatments for diabetes mellitus relied mainly on dietary measures including traditional medicines derived from plants. During this century the dietary recommendations for diabetes have turned full circle, with the renewed appreciation that carbohydrate-rich high-fibre diets can benefit the control of glycaemia and improve certain diabetic complications (Nutrition Sub-Committee of the British Diabetic Association, 1980; Mann, 1984; Vinik \& Jenkins, 1988). Traditional plant medicines for diabetes, which were abandoned in occidental societies as conventional drugs emerged, are now receiving renewed interest as adjuncts to conventional treatments and as potential sources of new hypoglycaemic compounds (Day \& Bailey, 1988a; Day, 1990). Most of these traditional medicines are prepared from herbs, spices and plants which do not form part of the normal diet (Day \& Bailey, 1988b; Bailey \& Day, 1989). However, several common components of the diet are traditionally recommended for regular consumption, and some are additionally taken as infusions, decoctions or alcoholic extracts.

The present review considers the dietary adjuncts which are used as traditional treatments for diabetes in the UK (Table 1), and describes studies to evaluate their efficacy.

\section{TRADITIONAL TREATMENTS FOR DIABETES}

Diabetes is a major disorder of industrialized and non-industrialized societies (World Health Organization, 1980). Traditional medicines continue to form the mainstay of treatment in more remote and underdeveloped areas where conventional medicines are unavailable or unaffordable. Traditional medical practices remain culturally strong in Asia, especially the Orient, and amongst a minority of enthusiasts in Western societies. A compendium of traditional plant treatments for diabetes now lists over 700 different species with reputed remedial efficacy (C. Day, unpublished results). However, very few of these plants have been investigated, and the majority await adequate scientific and medical evaluation. Several have been shown to assist glycaemic control in non-insulindependent forms of diabetes, but there is no known botanical substitute for insulin.

An example of the dietary basis for traditional anti-diabetic treatments is found in the Ebers Papyrus of $1550 \mathrm{BC}$ which prescribes a diet rich in wheatgerm and ochra (The Papyrus Ebers, 1937). The value of this therapeutic approach has been supported by subsequent research. Collip (1923), who contributed to the discovery of insulin, demonstrated that a parenterally administered extract of wheat leaves reduced blood sugar concentrations in normal rabbits. Recently, an extract of ochra was shown to lower glycaemia after parenteral administration to normal and alloxan diabetic mice (Tomoda 
Table 1. Traditional dietary adjuncts used in the treatment of diabetes mellitus in the UK

\begin{tabular}{|c|c|c|}
\hline \multicolumn{3}{|l|}{ Herbs and spices } \\
\hline Agrimony & Agrimonia elupatoria & Leaf \\
\hline Burdock & Arctium lappa & Leaf \\
\hline Chile pepper & Capsicum fructescens & Secd \\
\hline Coriander & Coriandrum sarivum & Seed \\
\hline Dandelion & Tararacum officinale & Root and leaf \\
\hline Ginger & Zingiber officinale & Root \\
\hline Goat's rue & Galega officinalis & Leaf \\
\hline Java plum & Syzgium jambos & Fruit and seed \\
\hline Liquorice & Glycyrrhiza glabra & Root \\
\hline Nettle & Urtica dioica & Aerial parts \\
\hline Sage & Salvia officinale & Lea: \\
\hline Sumach & Rhus species & Root, bark and leaf \\
\hline Tarragon & Artemisia dracunculus & Leaf \\
\hline Thyme & Thymus vulgaris & Leaf \\
\hline \multicolumn{3}{|l|}{ Vegctables } \\
\hline Cabbage & Brassica oleracea & Leaf \\
\hline Garlic & Allium sativum & Bulb \\
\hline Haricot bean & Phasoelus vulgaris & Pod \\
\hline Lettuce & Letuca sativa & Leaf \\
\hline Onion & Allium repa & Bulb \\
\hline Pea & Pisum sativum & Seed \\
\hline Potato & Solanum tuberosum & Tuber \\
\hline Sweetcorn & Zea may's & Style \\
\hline Turnip & Brassica rapa & Root \\
\hline \multicolumn{3}{|l|}{ Mushrooms } \\
\hline Edible mushroom & Agaricus bisporus & Fruiting body \\
\hline Lawyer's wig & Coprinus comatus & Fruiting body \\
\hline \multicolumn{3}{|l|}{ Fruits } \\
\hline Apple & Pyrus malus & Fruit \\
\hline Blackberry & Rubus fructicosus & Leaf \\
\hline Elder & Sambucus nigra & Leaf \\
\hline Hop & Humulus lupulus & Leaf \\
\hline Juniper & Juniperus communis & Berry \\
\hline Lemon & Citrus limonium & Fruit \\
\hline Lime & Tilia europa & Fruit \\
\hline Raspberry & Rubus idneus & Fruit \\
\hline \multicolumn{3}{|l|}{ Yeast } \\
\hline Brewer's yca!t & Saccharomyces cerevisiae & Cell extract \\
\hline \multicolumn{3}{|l|}{ Imported treatments } \\
\hline Lucerne & Medicago sativa & Leaf \\
\hline Cerasec & Momordica charantia (wild) & Aerial parts \\
\hline Eucalyptus & Eucalyptus globulus & Leaf \\
\hline Guayusa & Ilex guayusa & Leaf \\
\hline Karela & Momordica charantia (cultivated) & Fruit \\
\hline Mistletoe & Viscum album & Leaf \\
\hline
\end{tabular}

et al. 1987). It is recognized that oral consumption of plants such as these usually reduces the rate of intestinal glucose absorption due to the high fibre content. Thus, dietary fibre lowers post-prandial hyperglycaemia and may additionally confer a beneficial lipidlowering and anti-hypertensive effect (Vinik \& Jenkins, 1988). The bridge between 
traditional treatment, dietary supplement and pharmaceutical entity is illustrated by guar gum, a galactomannan fibre extracted from the seeds of the Indian cluster bean, Cyamopsis tetragonolobus. The seeds and the pods of this plant are used as a traditional treatment for diabetes in Asia (Pillai et al. 1980). The fibre component of the seeds is an established bulking agent in the food industry, and the pure extract is available as a dietary adjunct for the treatment of diabetes (Day, 1986; Vinik \& Jenkins, 1988).

\section{TRADITIONAL TREATMENTS IN THE UK}

Herbs and spices. Culpepper's Herbal is not specific on the diagnosis and treatment of diabetes, but the British Herbal Pharmacopoeia lists goat's rue (Galega officinalis), Java plum (Syzgium jambos or Eugenia jambolana), nettle (Urtica dioica) and sumach (Rhus typhina) as suitable palliatives for the diabetic patient (British Herbal Medizine Association, 1979). Goat's rue is renowned as a traditional treatment for diabetes throughout Europe, and its glucose-lowering effect has been demonstrated in animals (Sterne, 1969). It is rich in guanidine, a hypoglycaemic substance which is toxic if consumed chronically in large amounts. Guanidine probably accounts for the antihyperglycaemic effect of guayusa, a herbal preparation from the leaves of Ilex guayusa (Fig. 1; Swanston-Flatt et al. 1989b). Moreover, guanidine has provided the molecular template for the biguanide class of anti-hyperglycaemic drugs, such as metformin (Bailey, 1988). Extracts from the seeds and fruits of Java plum have been reported to exert a hypoglycaemic effect in diabetic animals and this treatment is widely recommended in Europe and Asia (Ajgaonkar, 1979; Bever \& Zahnd, 1979). An alcoholic extract of sumach leaves lowered blood glucose concentrations in diabetic animals (Gusienov \& Yuzbashinskaya, 1971), but claims that a decoction of nettle leaves are beneficial for diabetes were not substantiated in our studies with streptozotocin-diabetic mice (Swanston-Flatt et al. 1989b). In fact nettle actually aggravated the diabetic condition (Fig. 2).

Several herbs and spices found in the British kitchen have been attributed special value in the diabetic diet, particularly chile pepper (Capsicum fructescens), coriander (Coriandrum sativum), ginger (Zingiber officinale), sage (Salvia officinale), tarragon (Artemisia dracunculus) and thyme (Thymus vulgaris) (Vohora et al. 1973; Duke, 1985; Bailey \& Day, 1989). Three of these have received preliminary investigation in our laboratory. Sage did not significantly affect glucose concentrations in severely-streptozotocindiabetic mice, but showed a mild anti-hyperglycaemic action in normal glucose-loaded mice (Swanston-Flatt et al. 1989b). Tarragon reduced body-weight loss, polydipsia and hyperphagia in streptozotocin-diabetic mice without a significant lowering of glucose concentrations (Swanston-Flatt et al. 1989a). Coriander also decreased body-weight loss and additionally reduced the extent of hyperglycaemia in streptozotocin-diabetic mice (Fig. 3; Swanston-Flatt et al. 1990).

Vegetables. Many other plant preparations have been used in British folklore medicine to treat diabetes, although their reputed effects have not been critically investigated (Day \& Bailey, 1988b). A selection of common dietary vegetables is widely acclaimed, including cabbage (Brassica oleracea), haricot bean (Phaseolus vulgaris), lettuce (Letuca sativa), onion (Allium cepa), pea (Pisum sativum), potato (Solanum tuberosum), sweetcorn (Zea mays), and turnip (Brassica rapa). These are presumed to provide increased fibre in the diet, although some parenterally active fractions have been 


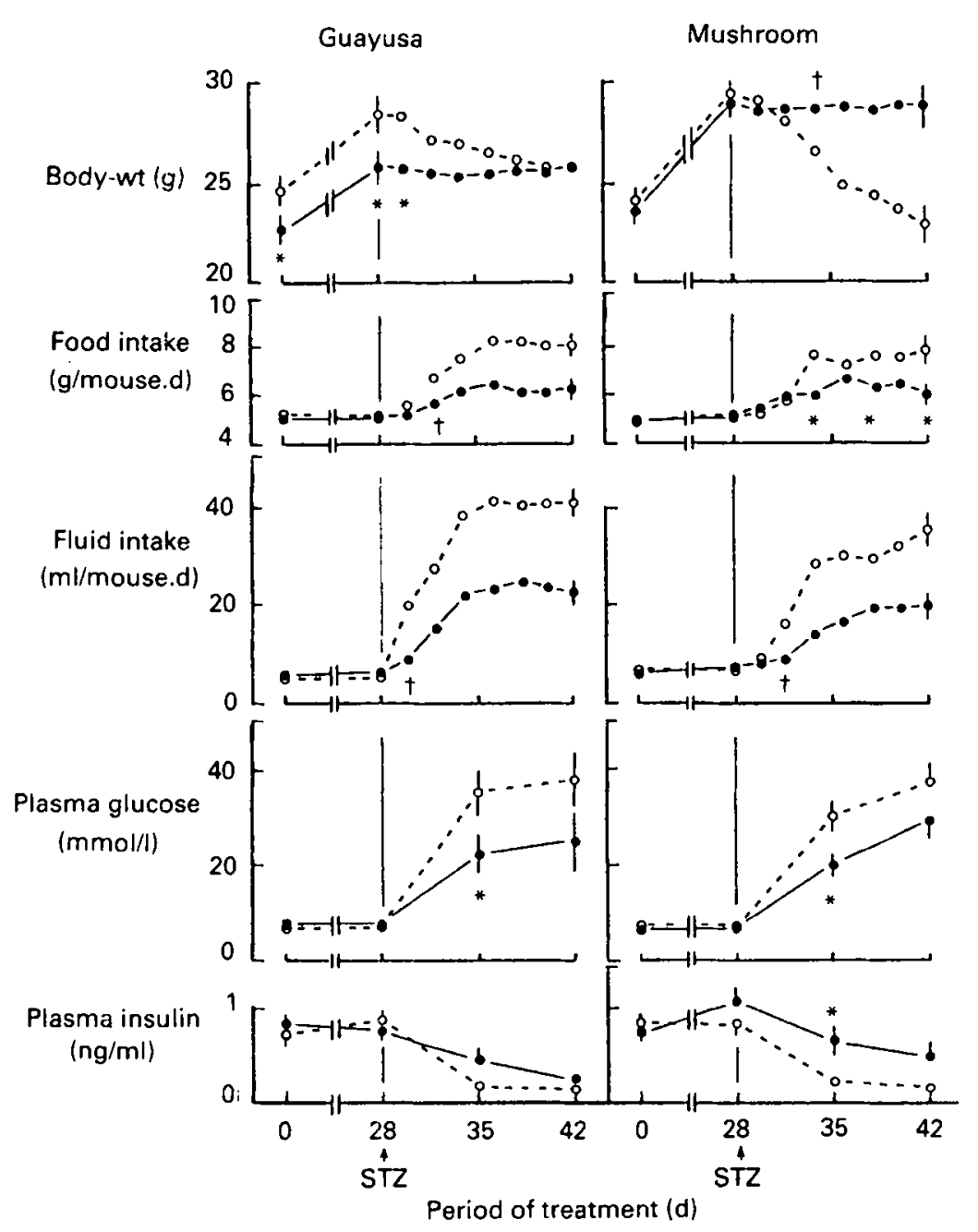

Fig. 1. Effect of guayusa and mushroom (Agaricus bisporus) on body-weight, food and fluid intake, and plasma glucose and insulin concentrations in non-diabetic (days 0-28) and streptozotocin-diabetic (days 28-42) mice. Guayusa was obtained from a French Druid Herbalist courtesy of the British Diabetic Association. The preparation was diluted $1 \mathrm{ml}$ in $100 \mathrm{ml}$ water and supplied to the mice in place of drinking water. Dried fruiting

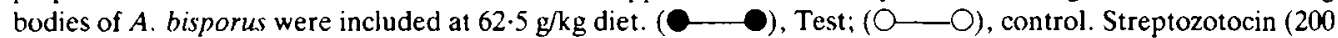
$\mathrm{mg} / \mathrm{kg}$ intraperitoneally) was administered on day 28 to induce a state of diabetes (STZ). Values are means with their standard errors, represented by vertical bars, for five animals. Mean values were significantly different from those for controls at the same time: ${ }^{*} P<0 \cdot 05$; mean values were significantly different from those for controls at the same time and at all subsequent times during the study: $\dagger P<0 \cdot 05$. Reproduced with permission from Swanston-Flatt et al. (1989h).

described (Bailey \& Day, 1989). As reviewed elsewhere, non-fibrous extracts with glucose-lowering activity in normal and diabetic animals have been obtained from leaves of cabbage and lettuce, pods of haricot beans, styles of sweetcorn, tubers of potatoes and roots of turnip (Peters, 1957; Bever \& Zahnd, 1979; Bailey \& Day, 1989). However, convincing evidence of their value in diabetic patients is lacking. 


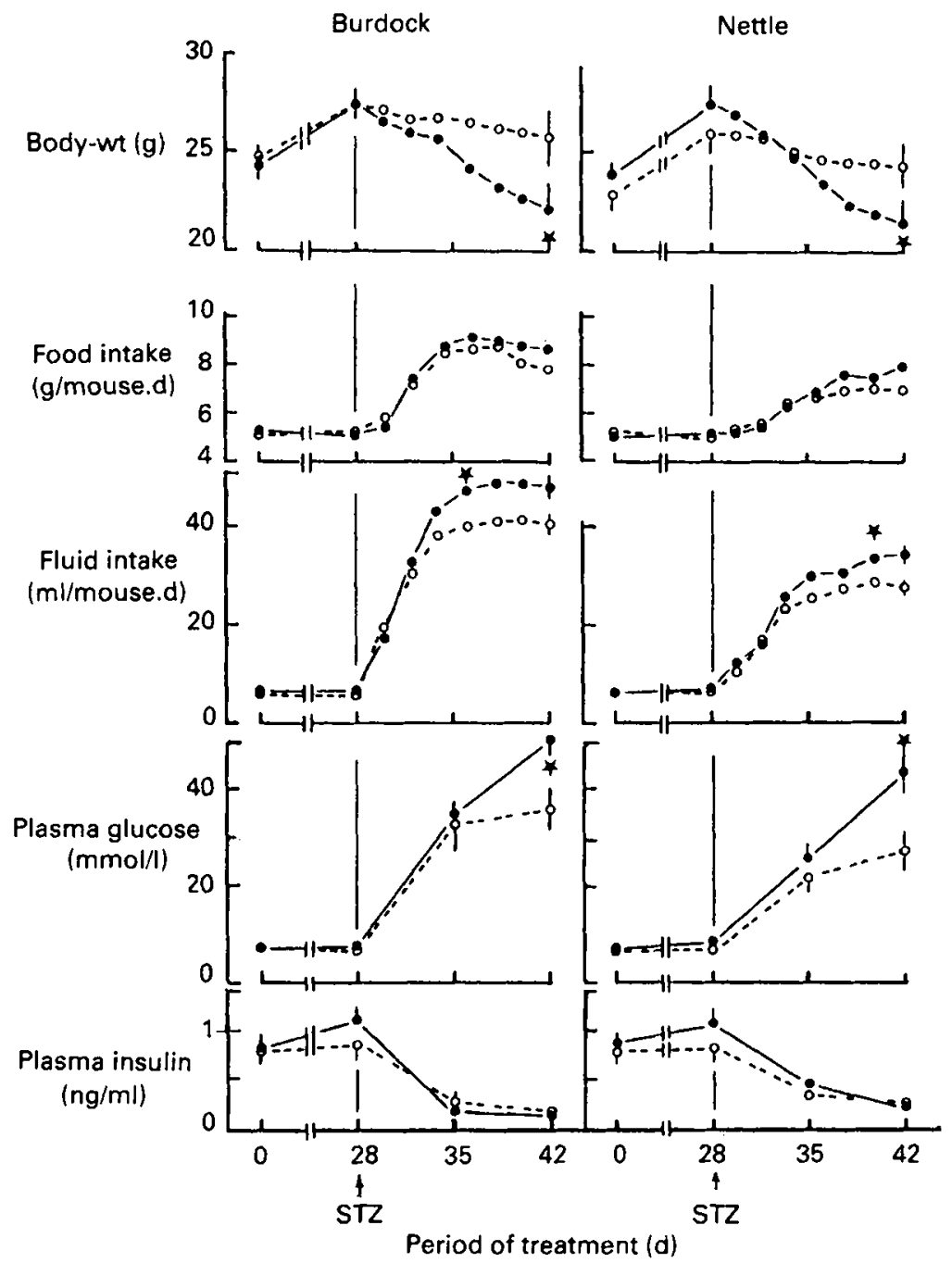

Fig. 2. Effect of burdock (Arctium lappa) and nettle (Urtica dioica) on body-weight, food and fluid intake, and plasma glucose and insulin concentrations in non-diabetic (days 0-28) and streptozotocin-diabetic (days 28-42) mice. Dried leaves of burdock and nettle were supplied as $62.5 \mathrm{~g} / \mathrm{kg}$ diet and as a decoction $(1 \mathrm{~g}$ in $400 \mathrm{ml})$ in place of drinking water. $\left(\mathrm{O}_{-}\right)$, Test; $(\mathrm{O}-\mathrm{O})$, control. Streptozotocin $(200 \mathrm{mg} / \mathrm{kg}$ intraperitoneally) was administered on day 28 to induce a state of diabetes (STZ). Values are means with their standard errors, represented by vertical bars, for five animals. Mean values were significantly different from those for controls at the same time and at all subsequent times during the study: ${ }^{*} P<0 \cdot 05$. Reproduced with permission from Swanston-Flatt et al. (1989b).

Onion has been especially recommended in many societies, and several studies have suggested that two volatile disulphide extracts (allyl-propyl disulphide and diallyldisulphide oxide) exert hypoglycaemic activity in non-insulin-dependent diabetic states (Day, 1990). Oral administration of a concentrated aqueous extract of onion bulb improved oral glucose tolerance without altering the plasma insulin response in normal mice (Fig. 4). An acute effect of the extract was not observed in severely hyperglycaemic streptozotocin-diabetic mice, although a weakly beneficial effect occurred after chronic 


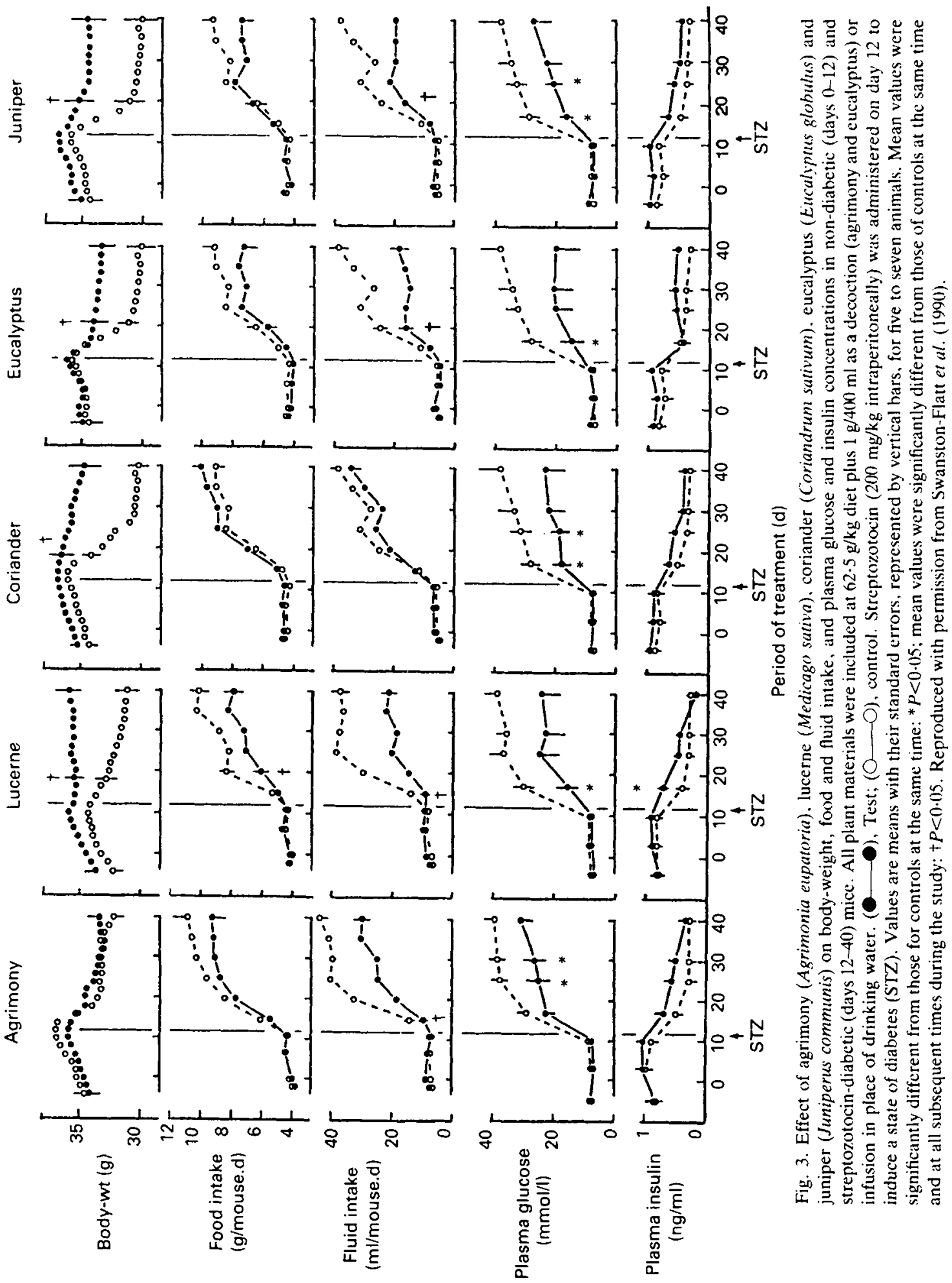




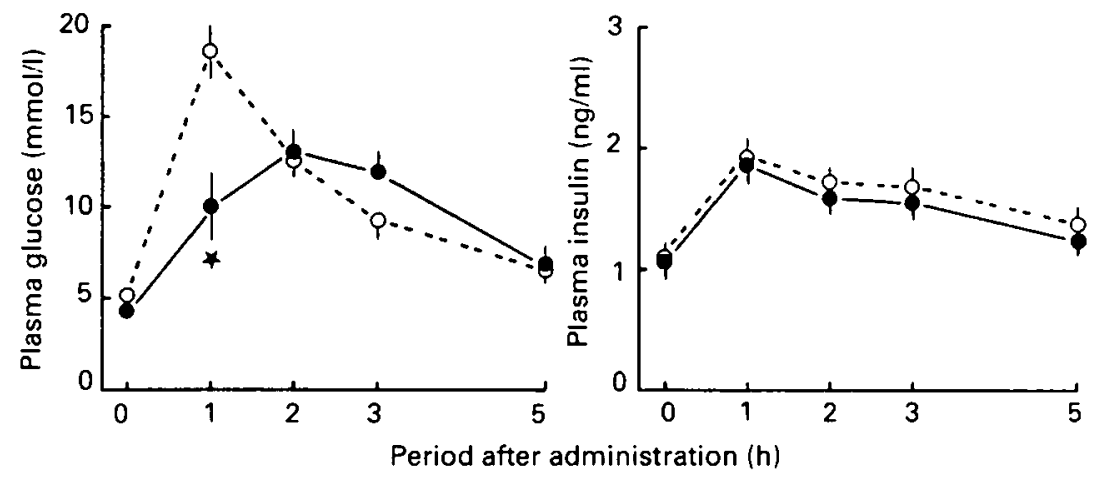

Fig. 4. Oral glucose tolerance and plasma insulin response to glucose in $18 \mathrm{~h}$ fasted normal mice immediately after oral administration of a concentrated aqueous extract of onion bulb (Allium cepa). The amount of extract administered was equivalent to $30 \mathrm{~g}$ raw onion bulb/kg body-weight. $\left(O_{-}\right)$, Onion: $(O-O)$, control. Values are means with their standard errors, represented by vertical bars, for five animals. Mean values were significantly different from those of mice not receiving onion: ${ }^{*} P<0 \cdot 0.5$. Reproduced with permission from Swanston-Flatt et al. (1991).

administration (Swanston-Flatt et al. 1991). Garlic (Allium sativum) has also been shown to improve glycaemic control in mild, but not severe forms of diabetes (Swanston-Flatt et al. 1990).

Mushrooms. Various mushrooms have been ascribed anti-diabetic properties including the common edible mushroom Agaricus bisporus. A diet containing $62.5 \mathrm{~g}$ dried fruiting bodies of $A$. bisporus $/ \mathrm{kg}$ reduced the rate of onset and the severity of hyperglycaemia in streptozotocin-diabetic mice (Swanston-Flatt et al. 1989b). Hyperphagia, polydipsia and body-weight loss were also reduced (Fig. 1). A. bisporus also retarded the decline in plasma insulin concentrations and pancreatic insulin content, and improved the hypoglycaemic effect of exogenous insulin. This suggests that $A$. bisporus may oppose both insulin deficiency and insulin resistance. These two effects may not be unrelated since an improvement in the function of insulin-secreting pancreatic $\beta$ cells would counter insulin resistance and vice versa. A lectin from $A$. bisporus (fraction PHA-B) has been shown to stimulate insulin release from isolated rat islets (Ewart et al. 1975), associated with increased calcium uptake (Ahmad et al. 1984), and a separate insulin-like effect has been observed in isolated adipocytes (Ewart et al. 1975).

Lawyer's wig (Coprinus comatus) is another mushroom anecdotally claimed to benefit glycaemic control in diabetes. An acute glucose-lowering effect has been reported in normal rats and mice, and a chronic reduction in basal glycaemia and improved glucose tolerance were noted in normal mice consuming a diet containing $330 \mathrm{~g}$ dried fruit bodies of $C$. comatus $/ \mathrm{kg}$ (Lelley, 1983; Bailey et al. 1984). However, this amount of $C$. comatus impaired the normal rate of body-weight gain in growing mice. In other European countries diets containing small amounts of Hypholoma hydrophilum, Psathyrella hydrophylum, Tricholoma gambosum and $T$. georgii are purported to improve the 
diabetic condition, and a selection of different mushrooms is similarly regarded in oriental countries (Potron, 1956; Kronberger, 1964: Day, 1990). The consumption of exotic or unusual mushrooms as treatment for diabetes is rightly viewed with caution: for example, the toxic effect of the deathcap mushroom (Amonita phalloides) is due to its hypoglycaemic effect which results from the depletion of hepatic glycogen.

Fruits and teas. Apple, lemon, lime and raspberry are traditionally deemed advantageous inclusions in the diet of diabetic patients, but controlled investigations have not been reported. Berries of juniper (Juniperus communis) and a decoction of agrimony leaves (Agrimonia eupatoria) are also reputedly beneficial, and studies in streptozotocindiabetic mice have substantiated a glucose-lowering effect and an improvement in other features of the diabetic state (Fig. 3; Swanston-Flatt et al. 1990). Amongst herb teas and coffees a decoction of blackberry leaves (Rubus fructicosus) and an infusion of elder leaves (Sambucus nigra) are also recommended, but studies in severely diabetic animals failed to show an effect (Swanston-Flatt et al. 1989b, 1990). However, a decoction of liquorice roots (Glycyrrhiza glabra) ameliorated the polydipsia and hyperphagia of diabetic mice without significantly lowering plasma glucose (Swanston-Flatt et al. 1990. 1991). Decoctions prepared from the roots and leaves of dandelion (Taraxacum officinale) were ineffective in severely diabetic mice, and a leaf decoction of burdock (Arctium lappa) worsened the diabetic condition (Fig. 2; Swanston-Flatt et al. 1989b). Hop (Humulus lupulus), taken as a leaf decoction has been ascribed hypo- and hyperglycaemic properties, but no significant alteration in plasma glucose was observed in streptozotocin-diabetic mice (Swanston-Flatt et al. 1989b).

Yeast. Brewer's yeast (Saccharomyces cerevisiae) is a rich source of chromium and the B-vitamins, which may be deficient in some forms of diabetes. Brewer's yeast has long been held to contain a factor which improves glucose tolerance, but no effect on glycaemic control was evident in spontaneously diabetic $d b$ - $d b$ mice (Flatt et al. 1989).

\section{TRADITIONAL TREATMENTS INTRODUCED INTO THE UK}

Immigrants to the UK have brought with them traditional treatments for diabetes which they continue to use as adjuncts or alternatives to conventional medicines (Bailey et al. 1986). Fruits of the cultivated variety of Momordica charantia (karela) are consumed as a cooked vegetable in Asian diets, and they are highly regarded for the treatment of diabetes. For medicinal purposes the fruit is sometimes consumed raw or crushed to form a juice. In a group of non-insulin-dependent diabetic patients $50 \mathrm{ml}$ karela juice acutely improved oral glucose tolerance without altering the insulin response to glucose. Daily consumption of $0.23 \mathrm{~kg}$ fried karela for 8-11 weeks reduced the percentage of glycated haemoglobin and improved oral glucose tolerance (Leatherdale et al. 1981). On a cautionary note, the effect of karela may be additive to or able to potentiate the action of sulphonylureas, thereby increasing the risk of hypoglycaemia (Aslam \& Stockley, 1979). The mode of action of karela has been studied in normal and streptozotocin-diabetic animals. A decreased rate of intestinal glucose absorption has been claimed (Meir \& Yaniv, 1985), but this cannot be a major effect since aqueous extracts show similar glucose-lowering activity when administered orally or parenterally (Day et al. 1990). Although orally administered extracts of karela do not raise circulating insulin concentrations. increased insulin release was reported after incubation of extracts with isolated pancreatic islets (Welihinda et al. 1982). Studies with isolated hepatocytes indicate that 
karela can decrease hepatic glucose production by suppression of gluconeogenesis (Day, 1990). Attempts to identify the active principle(s) of karela have yielded weakly acting components within the alkaloid and glucoside fractions (Day et al. 1990).

The wild variety of Momordica charantia (cerasee) has been introduced into the UK from the West Indies, where it is prepared as a tea and imbibed as a general prophylactic and treatment for diabetes. Parenteral administration of cerasee decreased basal plasma glucose concentrations in normal and streptozotocin-diabetic mice, and improved glucose tolerance in normal mice. Like karela, cerasee was effective without increasing insulin concentrations (Bailey'et al. 1985).

A tea prepared from leaves of mistletoe (Viscum album) is another traditional treatment for diabetes introduced from the West Indies. Although this treatment did not significantly lower glucose concentrations in severely hyperglycaemic streptozotocindiabetic mice, other symptoms such as polydipsia, hyperphagia and body-weight loss were ameliorated (Swanston-Flatt et al 1989a).

An infusion of lucerne (Medicago sativa) is used traditionally to treat diabetes in South Africa, and its fame has spread to many countries including Britain. A classic case study described an insulin-dependent patient who rapidly developed severe symptoms of hypoglycaemia on each occasion that he consumed such an infusion (Rubenstein et al. 1962). Lucerne is a rich source of manganese, and consumption of manganese chloride produced a similar hypoglycaemic effect. It is possible that some diabetic patients become $\mathrm{Mn}$ deficient, and since $\mathrm{Mn}$ is a cofactor for insulin-receptor phosphorylation, Mn deficiency might impair insulin action. Studies in streprozotocin-diabetic mice were consistent with claims of an insulin-sparing effect of lucerne. In this animal model lucerne reduced the hyperglycaemia and improved other features of the diabetic condition (Fig. 3; Swanston-Flatt et al. 1990).

A traditional remedy originating from Africa and South America is a decoction of eucalyptus leaves (Eucalyptus globulus). This treatment reduced the hyperglycaemia. polydipsia and weight loss in streptozotocin-diabetic mice (Fig. 3; Swanston-Flatt et al. 1990).

\section{ROLE FOR TRADITIONAL TREATMENTS}

Since conventional dietary therapy and hypoglycaemic drugs provide effective treatments for diabetic conditions it is pertinent to ask whether there remains a role for traditional anti-diabetic plant treatments in occidental societies. Those plants which are known to possess glucose-lowering activity and form part of the normal diet may be accorded some preference in the design of diabetic diets. Consumed in moderation they could be beneficial for diet-only-treated non-insulin-dependent diabetic patients, and such diets might even afford a degree of protection for those at risk of developing glucose intolerance. For patients already treated with oral hypoglycaemic drugs (sulphonylureas or metformin), diets containing glucose-lowering plants could also be beneficial if consumed on a regular basis. The possibility of interaction with conventional drugs or an additive effect which could lead to hypoglycaemia should be appreciated. However, the glucose-lowering potency of these dietary adjuncts is generally too low to render this a serious risk. For patients receiving insulin, the problem of hypoglycaemia is paramount, and irregular or overindulgence in any other hypoglycaemic remedy should be discouraged unless rigorous monitoring is observed. Although a toxic effect of most traditional 
British foods is unlikely if consumed in normal dietary amounts, 'natural' does not necessarily imply 'safe', particularly if consumed chronically in excessive amounts. Caution is, therefore, especially relevant if traditional infusions or decoctions are taken. We conclude that some traditional plant treatments for diabetes possess glucoselowering activity. Employed judiciously they can provide useful dietary adjuncts to conventional therapies.

Research from the authors' laboratories was supported by the British Diabetic Association and the University of Ulster Research Selectivity Committee. C.D. gratefully acknowledges the support of the Leverhulme Trust.

\section{REFERENCES}

Ahmad. N., Bansal. R.. Rastogi, A. K. \& Kidwai, J. R. (1984). Effect of a PHA-B fraction of Agaricus bisporus lectin on insulin release and ${ }^{+5} \mathrm{Ca}^{2+}$ uptake by islets of Langerhans in vitro. Acta Diabetologia Latina 21. 63-70.

Ajgaonkar. S. S. (1979). Herbal drugs in the treatment of diabetes: a review. International Diabetes Federation Bulletin 24, 10-17.

Aslam, M. \& Stockley, I. H. (1979). Interaction between curry ingredient (karela) and drug chlorpropamide. Lancel i, 607.

Bailey, C. J. (1988). Metformin revisited: its actions and indications for use. Diabetic Medicine 5, 315-320.

Bailey, C. J. \& Day, C. (1989). Traditional plant medicines as treatments for diabetes. Diabetes Care 12, 553-564.

Bailey, C. J., Day, C. \& Leatherdale, B. A. (1986). Traditional treatments for diabetes from Asia and the West Indies. Practical Diabetes 3, 190-192.

Bailey, C. J., Day. C.. Turner, S. L. \& Leatherdale, B. A. (1985). Cerasee, a traditional treatment for diabctes. Studies in normal and streptozotocin diabetic mice. Diabetes Research 2, 81-84.

Bailey, C. J., Turner, S. L., Jakeman, K. J. \& Hayes, W. A. (1984). Effect of Coprinus comatus on plasma glucose concentrations in mice. Planta Medica 50, 525-526.

Bever, B. O. \& Zahnd. G. R. (1979). Plants with oral hypoglycaemic action. Quarterly Journal of Crude Drug Research 17, 139-196.

British Herbal Medicine Association (1979). British Herbal Pharmacopoeia. Keighley: The British Herbal Medicine Association.

Collip. J. B. (1923). Glucokinin. A new hormone present in plant tissue. Journal of Biological Chermistry 56. 51.3-523.

Day, C. (1986). Guar gum. Industrial Biotechnology 6, 137-138.

Day, C. (1990). Hypoglycaemic compounds from plants. In New Antidiabetic Drugs, pp. 267-278 [C. J. Bailey and P. R. Flatt, editors]. London: Smith-Grordon.

Day, C. \& Bailey, C. J. (1988a). Hypoglycacmic agents from traditional plant treatments for diabetes. International Industrial Biotechnology 8, 5-8.

Day, C. \& Bailey, C. J. (1988b). A diabetologist's herbal. Current Medical Literature - Diabetes, Royal Socien of Medicine 5, 31-35.

Day, C.. Cartwright. T., Provost, J. \& Bailey, C. J. (1990). Hypoglycaemic effect of Momordica charantia extracts. Planta Medica 56, 426-429.

Duke. J. A. (1985). Handbook of medicinal herbs. Florida: CRC Press.

Ewart, R. B.L.. Kornfeld. S. T. \& Kipnis, D. M. (1975). Effect of lectins on hormone release from isolated rat islets of Langerhans. Diabetes 24, 705-714.

Flatt, P. R., Juntti-Berggren. L.. Berggren. P. -O. \& Swanston-Flatt, S. K. (1989). Failure of glucose tolerance factor-containing brewer's yeast to ameliorate spontaneous diabetes in C57BL/KsJ $\mathrm{db} / \mathrm{db}$ mice. Diabetes Research 10, 147-151.

Guseinov, D. Y. \& Yuzbashinskaya, P. A. (1971). Effect of a sumac (extract) on normal carbohydrate metabolism and alloxan-induced diabetes in rabbits. Chemical Abstracts 74, 30638.

Kronberger, K. (1964). Pilze und diabetes. Bericht Naturwissenschaft Giesellschaft Bayreuth 11, 231-235. 
Leatherdale, B. A., Panesar, R. K., Singh, G., Atkins, T. W., Bailey, C. J. \& Bignell, A. H. C. (1981). Improvement in glucose tolerance due to Momordica charantia (karela). British Medical Journal 282. 1823-1824.

Lelley. J. (1983). Investigations on the culture of the ink cap, Coprinus comatus (Mull ex Fr) Gray. Mushroom Journal 129, $1-6$.

Mann, J. (1984). Lines to legumes: changing concepts of diabetic diets. Diabetic Medicine 1, 191-198.

Meir, P. \& Yaniv, Z. (1985). An in vitro study on the effect of Momordica charantia on glucose uptake and glucose metabolism in rats. Plania Medica 51, 12-16.

Nutrition Sub-Committee of the British Diabetic Association Medical Advisory Committee (1980). Dietary recommendations for the 1980 s - a policy statement by the British Diabetic Association. Human Nurrition. Applied Nutrition 36, 378-386.

Peters, G. (1957). Ubersichten Insulin-Ersatzmittel pflanzlichen Ursprungs. Deutsch Medizin Wochenschrift $82,320-322$.

Pillai, N. R., Seshadri, C. \& Santhakumari, G. (1980). Hypoglycaemic effect of Cyamopsis tetragonoloba taub (gowar). Indian Journal of Medical Research 72, 128-131.

Potron, M. (1956). Champignons et diabète. Concurs Medical 36, 3795-3796.

Rubenstein, A. H., Levin, N. W. \& Elliott, G. A. (1962). Manganese-induced hypoglycacmia. Lancet ii, $1348-1351$.

Sterne, J. (1969). Pharmacology and mode of action of the hypoglycaemic guanidine derivatives. In Oral Hypoglycaemic Agents, pp. 193-245 [G. D. Campbell, editor]. New York: Academic Press.

Swanston-Flatt, S. K., Day, C., Bailcy, C. J. \& Flatt. P. R. (1989a). Evaluation of traditional plant treatments for diabctes: studies in streptozotocin diabetic mice. Acta Diabetologia Latina 26, 51-55.

Swanston-Flatt. S. K., Day, C., Bailey, C. J. \& Flatt, P. R. (1990). Traditional plant treatments for diabetes. Studies in normal and streptozotocin diabetic mice. Diabetologia 33, 462-464.

Swanston-Flatt, S. K., Day, C., Flatt, P. R. \& Bailey, C. J. (1991). Evaluation of the antihyperglycaemic properties of traditional plant treatments for diabetes in streptozotocin-diabetic and $\mathrm{db} / \mathrm{db} \mathrm{mice}$. In Frontiers in Diabetes Research. L.essons from Animal Diabetes, vol. 3, pp. 286-293 [E. Shafrir, editor]. London: Smith-Gordon.

Swanston-Flatt, S. K., Day, C., Flatt, P. R., Gould, B. J. \& Bailey, C. J. (1989b). Glycaemic effects of traditional European plant treatments for diabetes. Studies in normal and streptozotocin diabctic mice. Diabetes Research 10, 69-73.

The Papyrus Ebers (1937). The Papyrus Ebers: The Greatest Egyptian Medical Document. Copenhagen: Levin and Munksgaard.

Tomoda, M., Shimizu, N.. Oshima, Y., Takahashi, M. Murakami, M. \& Hikino. H. (1987). Hypoglycemic activity of twenty plant mucilages and three modified products. Planta Medica 53, 8-12.

Vinik, A. I. \& Jenkins. D. J. A. (1988). Dietary fiber in management of diabetes. Diabetes Care 11. $160-173$.

Vohora, S. B., Rizwan. M. \& Kahn, J. A. (1973). Medicinal uses of common Indian vegetables. Planta Medica 23, 381-393.

Welihinda, J., Arvidson, G., Gylfe, E., Hellman, B. \& Karlsson, E. (1982). The insulin-releasing activity of the tropical plant Momordica charantia. Acta Biologica et Medica Germanica 41, 1229-1240.

World Health Organization (1980). Second Report of Expert Committee on Diabetes Mellitus. Technical Report Series no. 646. Gencva: WHO. 